\title{
EVOLUTION OF INFAUNAL BIOEROSION IN THE EARLY PALEOZOIC
}

EKDALE*, A. A., Dept. of Geology \& Geophysics, University of Utah, Salt Lake City, UT 84112, U.S.A.; BROMLEY, R. G., Geologisk Institut, Øster Voldgade 10, 1350 København K, Denmark.

Boring into rock is a remarkable feat for an invertebrate animal. The ability to excavate lithified material is evolutionarily significant because of the requisite physiological and anatomical adaptations. Bioerosion also is ecologically important because of the novel niche and habitat possibilities opened up by an endolithic lifestyle.

The oldest macroborings are small Trypanites in Lower Cambrian archeocyathid reefs and associated hardgrounds. Lower Ordovician macroborings occur in hardgrounds in southern Scandanavia and western North America. In Middle and Upper Ordovician carbonate sequences, macroborings are relatively diverse and widespread.

The Early Ordovician is the time when the macroboring niche became firmly established and widely distributed in hard-substrate communities in shallow-marine environments. In the Baltic region at that time, numerous repetitive omission surfaces developed in bioclastic limestones that exhibit complex, composite ichnofabrics. Firmground trace fossil associations, dominated by Thalassinoides and other branching burrows, and hardground associations, including vase-shaped Amphorichnus and other borings, are overprinted on a background ichnofabric of softground burrows. No body fossils of the borers are preserved, so their biological affinities are unknown. Because of the absence of any preserved skeletal structures that might have aided the borers in mechanical drilling, it is presumed that the boring activity must have been accomplished by purely chemical means.

The authors examined Lower Ordovician borings in Norway and Sweden. Similar borings are reported by other workers in Estonia. Endolithic colonization of the entire Early Ordovician sea floor in the Baltic region therefore must have occurred extensively and rapidly. If some of the borings in the Baltic region are unique to Lower Ordovician strata, as Amphorichnus appears to be, then they could be useful as biostratigraphic indices. If that is the case, the question looms as to why such specialized infaunal behavior and unusual bioeroding capabilitities were evolutionarily unsuccessful.

The appearance of large, diverse macroborers in the Early Ordovician was a major milestone in evolution, because it represents the development of novel physiologic attributes (if chemical borers), functional anatomical structures (if mechanical borers) and ecologic strategies (as endolithic inhabitants). The Ordovician trace fossil record in the Baltic region reflects an expansion of the endobenthos following an oceanic oxygen crisis in the Late Cambrian. Normal marine conditions in the Early Ordovician spawned a major biologic diversification, which is represented by diverse benthic communities that included both burrowers and borers as major constituents. The development of the rockboring ability by organisms demonstrates the selective advantage of a new functional strategy for exploiting a range of new habitats that were unavailable to non-borers.

Computer-aided image analysis and fractal geometric analysis have proven useful in examining bioerosion ichnofabrics. The strikingly colored and extremely complex ichnofabrics in the Lower Ordovician hardgrounds are ideal subjects for such techniques, which are helpful in understanding the complexities that resulted from superimposition of softground, firmground and hardground suites of burrows and borings. 